\title{
Assessment and Optimization of Energy use of Yellow Oleander (Thevetia Peruviana) for Biodiesel Blends in Nigeria
}

\author{
F. A. Adamu' ${ }^{1}$, B. G. Jahun ${ }^{2}$, C. Daniel ${ }^{1}$ \\ ${ }^{1}$ Department of Agricultural and Environmental Engineering, School of Engineering and Engineering Technology, Modibbo Adama \\ University of Technology, Yola- Nigeria \\ ${ }^{2}$ Agricultural and Bioresource Engineering Department, Faculty of Engineering and Engineering Technology, Abubakar Tafawa Balewa \\ University, Bauchi - Nigeria
}

\begin{abstract}
In this study, Yellow oleander (Thevetia Peruviana) was assessed and optimized for biodiesel extraction. A 3.5kg of seeds was obtained, dried, cleaned, milled and 1.9 liters of oil was extracted by hand press. The oil was transesterified with 4 solvents blended within 6 rations and tested in a power point F165 single cylinder four stroke diesel engine. This was connected to aTD114 instrumentation under varying torque conditions for measuring engine performance. Engine parameters investigated includes among others are: Power developed and specific fuel consumption. Regression was analyzed based on torque fit line to examine the indices tested. The average exhaust emissions of carbons from diesel engine had effect on biodiesel blends and engine torque. Emission was found to decrease with the increase in proportion of biodiesel in the fuel blends, NOx increases with increase in biodiesel while $\mathrm{SO}_{2}$ decreased with increase in the ratio of biodiesel. Based on the studies on physicochemical properties of yellow oleander, it was discovered that oil obtained from non-edible seeds like yellow oleander has eco-friendly alternatives to diesel fuel that has higher effect of emissions which increase global warming. The objectives of the study was to ascertain the potential of Yellow oleander as an alternative to diesel fuel for an internal combustion engine while providing acceptable engine performance.
\end{abstract}

Keywords: Biodiesel, Yellow Oleander, Global warming, Pollutant, Biodegradable

\section{Introduction}

Worldwide, biodiesel production is mainly from edible oils such as Soybean, Sunflower and Canola oils that compete with the demand for human consumption. The term biodiesel was first commercialized in the United States in 1992 by National Biodiesel Board (NBB) [1]. Both biodiesel and diesel fuel are used for transport of industrial and agricultural goods, pumps and diesel tractor etc. Biodiesel has become more attractive recently because of its environmental benefits and the fact that it is made from renewable resources and biodegradable. Recently, environmental pollution caused by fossil fuels and non-renewable has led to search for less pollutant and renewable fuel [2-4]. However, the abundance of forest and plant based non-edible oils available in Nigeria, motivated researches on Yellow Oleander (Thevetia peruviana).

Yellow Oleander (Thevetia peruviana) belongs to the order apocynales of Apocynaceae family. It is a native of tropical America especially Mexico, Brazil and West Indies and has naturalized in tropical regions Worldwide. In spite of the high oil content $(67 \%)$ of its kernel [5] and favourable protein content $(37 \%)$ in the oil cake [6], it has remained only an ornamental, fencing or wasteland plant that has yellow, white or pinkish yellow coloured flowers ( Fig. 1).

The aim of the study is to investigate the performance of a portable Compression Ignition Engine (C.I) and gas emissions of Thevetia peruviana biodiesel blended with conventional diesel fuel (CDF) at blend ratios (B10, B20, B30, B40, B50).

\section{Material and Methods}

Yellow oleander (Thevetia peruviana) Seeds, Methanol, Potassium hydroxide $(\mathrm{KOH}), \mathrm{n}-\mathrm{Hexane}$ and phenolphthalein, Weighing scale, Glass beaker, Conical flask, Hydrometer, Kerosene stove, Viscometer, CI Engine (power point F165), Measuring cylinder, Smoke Analyzer, Crowncon gas, thermometer, detector for air pollutants, Refrigerator, TD114 Instrumentation, Milling machine and Stop watch.

$3.5 \mathrm{~kg}$ of yellow oleander seeds was obtained, dried, cleaned, milled and 1.9 liters of oil was extracted by hand press as reported by [7]. The experiment was conducted using different blends derived from Thevetia peruviana biodiesel and $\mathrm{CDF}$ at the varied ratios as shown in Plate 2.
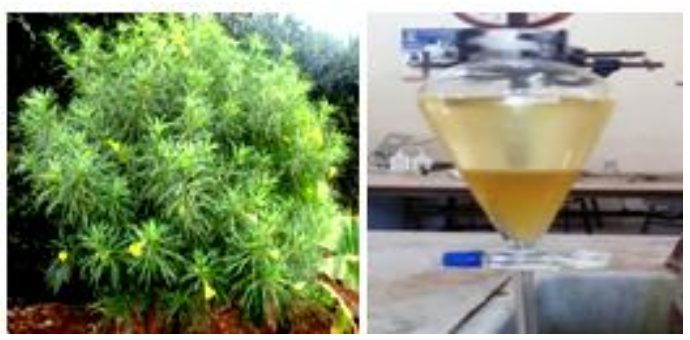

Figure 1: Yellow Oleander tree and Plate 1) Varied ratios of different blends derived from Thevetia peruviana biodiesel and $\mathrm{CDF}$.

\subsubsection{Characterization of Thevetia peruviana Biodiesel}

Characterization of Thevetia peruviana biodiesel was carried out in the Laboratory using the standard methods as reported by [8].

\section{Volume 4 Issue 11, November 2015}




\section{International Journal of Science and Research (IJSR) \\ ISSN (Online): 2319-7064}

Index Copernicus Value (2013): 6.14 | Impact Factor (2014): 5.611

2.2.2 Biodiesel properties: Cetane index, cloud point, pours point, flash point, calorific value, kinematic viscosity and specific gravity as reported by [9].

\subsubsection{Cetane index determination}

The cetane index is a measure of the quality of the biodiesel and was determined from the (1):

Centane index $=46.3+\left(\frac{5458}{S_{v}}\right)-0.225 x I_{v}[12](1)$

Where,

$\mathrm{S}_{v}=$ Saponification

$I_{v}=$ Iodine value

The values of saponification and iodine have already been determined [10].

\subsubsection{Cloud point of biodiesel}

Determined by cooling the biodiesel in ice $/ \mathrm{NaCl}$ mixture and the surface was observed until a cloud formation was seen on the surface of the biodiesel. The temperature was then recorded as the cloud point of the biodiesel[9].

\subsubsection{Pour point}

Determined by placing the biodiesel in ice $/ \mathrm{NaCl}$ until it almost start freezing. The test tube was then tilted until the first sign of pouring was observed in the diesel. The temperature was recorded as the pour point of the biodiesel [11].

\subsubsection{Flash point}

Determined by heating the biodiesel on a petri dish connected to a thermometer, and passing a flame over it, until a pop sound was heard. The temperature was recorded as the flash point of the biodiesel[11].

\subsubsection{Calorific value}

Estimated using a Bomb Calorimeter as reported by [10].

\subsubsection{Kinematic viscosity}

Each sample was sucked into a 150 capillary viscometer to fill the retention bulb and then corked. The capillary viscometer was inserted into a viscosity water bath set at $40^{\circ} \mathrm{C}$ and allowed to remain for five minutes. The cork was removed and the oil allowed to flow under gravity. The time taken for the biodiesel to flow from one designated point to another on the capillary was recorded using a stop watch. The procedure was replicated five times for measurement of flow time. From the two measurements of flow time, a determined kinematic viscosity value was calculated and the average of these determined values was used to calculate the kinematic viscosity [8] as represented in (2).

$$
V_{1.2}=C . t_{1.2}
$$

Where,

$V_{1.2}=$ determined kinematic viscocity values for $\mathrm{V}_{1}$ and $\mathrm{V}_{2}, \mathrm{~mm}^{2} / \mathrm{s}$

$C=$ calibration constant of the viscometer, $\mathrm{mm}^{2} / \mathrm{s}$ $t_{1.2}=$ measured flow times for $\mathrm{t}_{1}$ and $\mathrm{t}_{2}$, second

The kinematic viscosity result, $\mathrm{V}$, is an average of $\mathrm{V}_{1}$ and $\mathrm{V}_{2}$.

\subsubsection{Specific gravity}

$50 \mathrm{ml}$ of biodiesel sample each was measured into a $250 \mathrm{ml}$ glass beaker. The sample was inserted in a cold water bath to normalize the temperature at $15^{\circ} \mathrm{C}$. A hydrometer ranging from 0.8500-0.9000 was inserted in the sample and allowed to come to rest in its floating condition. The hydrometer mark was read off and recorded. The sample was left to attain $20^{\circ} \mathrm{C}$ under ambient temperature. The hydrometer was inserted into the sample at this temperature and the specific gravity read off. When the sample had attained ambient temperature of $31^{\circ} \mathrm{C}$, the hydrometer was inserted and the specific gravity recorded as reported by [12].

\subsubsection{Emission (Smoke) Analysis of the Samples}

The emission results for Nitrogen Oxides $\left(\mathrm{NO}_{2}\right)$, Carbon monoxide $(\mathrm{CO})$ and Sulphur dioxide $\left(\mathrm{SO}_{2}\right)$ were taken using a CROWNCON gas detector of air pollutants. All emissions were measured during steady-state engine operation.

\subsubsection{Engine Performance}

An internal combustion engine Power Point $165 \mathrm{~F}$ with rated power $2.43 \mathrm{KW}$ rated speed of $2600 \mathrm{rpm}$, was used as a convenient and compact source of power to test the performance of the engine based on the different blends of fuel as shown in Plate2.

The engine test was done using the above compression ignition (CI) engine with TD114 instrumentation unit (Plate 2 ). The test rig provided information on the efficiency with which the engine converts the chemical energy contained in the fuel to useful mechanical work. The engine was coupled to a hydraulic dynamometer to measure the engine torque and load control. In addition to housing the instruments for measuring the engine performance, the air consumption box viscous flow meter in TD114 instrumentation unit was used to measure the air flow of the engine. Engine speed was measured by tachometer, fuel mass flow rate was measured using stopwatch and calibrated glass tube in the TD114 instrumentation unit, the fuel consumption was determined by measuring the time taken for the engine to consume a given volume of fuel and a thermocouples was connected to TD114 to measure exhaust gas temperatures at the outlet pipes.

The operating condition was stabilized and the variables measured and recorded. These variables included dynamometer speed, torque, and rate of fuel, mass flow rate of air and the exhaust gas temperature. 


\section{International Journal of Science and Research (IJSR) \\ ISSN (Online): 2319-7064}

Index Copernicus Value (2013): 6.14 | Impact Factor (2014): 5.611

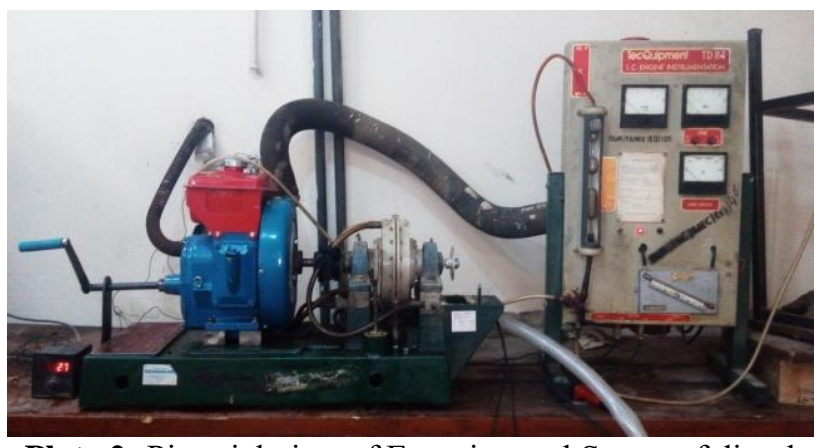

Plate 2: Pictorial view of Experimental Set up of diesel engine and TD114 instrumentation unit

\section{Results and Discussions}

The values obtained from characterization of Thevetia peruviana oil and Biodiesel are presented in Table 1, which shows the characteristics of the test fuel (Thevetia peruviana biodiesel) and conventional diesel fuel as determined following ASTM standards. The results shows that biodiesel from yellow oleander have lower density, kinematic viscosity and lower calorific value than CDF while B100 has higher flash point than the reference diesel, an indication of good fuel quality in terms of safety during transport, handling, and storage as reported by (Wang et al., 2000). Specific gravity and calorific values of CDF and the blends have almost equaled specific gravity and calorific values as compared with the values obtained in Table 2 with yellow oleander blends. This shows that there is a prospect and great chances of harnessing yellow oleander to produce a reliable biodiesel. The average values of Brake thermal efficiency, specific fuel consumption, power developed, exhaust gas temperature, airflow ratio and volumetric efficiency, air flow ration and gases emissions were presented in Table 3.

The blends show a rather inconsistent reaction to increase in torque, but it generally shows that with increase in torque there is a general and relative decrease in brake Thermal Efficiency (BTE) in all blends. Most of the water emulsified fuels exhibit lower BTE in low loads compared to diesel and biodiesel and show slight improvement in higher loads with respect to biodiesel. This is because the micro explosion phenomenon, due to volatility difference between water and fuels, enhances air fuel mixing during higher engine torque and hence improvement in combustion efficiency. Environmental Protection Agency (EPA) regulated emissions determined in this research were $\mathrm{CO}, \mathrm{NOx}$, and $\mathrm{SO} 2$. $\mathrm{CO}$ is a result of incomplete combustion and is formed mostly when fuels containing carbon are burned where there is too little oxygen. $\mathrm{CO}$ emissions from diesel engines are generally low since diesel engines operate fuel lean.

However, oxygenated fuels such as biodiesel can further reduce $\mathrm{CO}$ emissions because of the oxygen content in the fuel itself, which further promote complete combustion [13].
For example, [14, 15] found that there is a 12 percent reduction in $\mathrm{CO}$ emissions when using $\mathrm{B} 35$, which is 35 percent of biomass and 65 percent of petroleum diesel. The blending effect for the $\mathrm{NOx}, \mathrm{SO}_{2}$,

Co emissions is complicated and NOx emissions do not appear to be simply related to the blend percentage as characterized by the oxygen level [16]. Provisionally, one could estimate NOx emissions by a linear combination of petroleum fuel and neat biodiesel.

Regression analysis of BTE based on torque line fit shows $\left(\mathrm{R}^{2}\right) \mathrm{D} 100(91 \%), \mathrm{B} 10$ (92\%), B20 (97\%), B30 (91\%), B40 $(95 \%), \mathrm{B} 50(84 \%), \mathrm{B} 100(83 \%)$, this indicates that B20 and B40 have shown no significant difference on BTE Torque fit line. F and P values of D100, B10, B20, B30, B40, B50 and $\mathrm{B} 100$ have F-Values of $0.01,0.008,0.0014,0.01,0.004$, 0.027 and 0.029 respectively.

The significance $\mathrm{F}$ and $\mathrm{P}$ values are less than 0.05 but with B20 having the lowest values of $F$ shows no significant difference with increase in tongue on BTE as compared to the torque fit line. The regression line $\mathrm{Y}(\mathrm{BTE})=$ coefficients (intercept \pm Torque).The blends exhibited a higher fuel consumption at a lower torque and consumption decreased with all blends and CDF to a minimum, between 8.5 to $11.5 \mathrm{Nm}$. Despite the fact that the values are different with all the blends, B100 has the lowest value of BTE compared to the CDF which has the highest BTE which is similar to [5, 17], that BTE of biodiesel is less than that of diesel fuel due to its lower calorific value.

\section{Summary and Conclusion}

Biodiesel from Thevetia peruviana seed oil was produced in the laboratory by methanolysis estimated at $90 \%$ yield. Biodiesel delivered less power with increase in torque compared to $\mathrm{CDF}$ when used in the test engines. It is also found to decrease with increasing percentage of biodiesel in the fuel blends. Power is a function of the engine geometry, speed, air/fuel ratio, efficiencies, and fuel properties. Assuming that mechanical losses are similar and since there were no modifications made in the injection rates or duration for an individual test fuel, power loss may be attributed to the variation in the fuel properties such as heating values and densities between fuels. Moreover, the rise in mass flow for all biodiesel fuels as observed from the test engine can be attributed to the differences in the heating values of the test fuels. The biodiesel fuels have lower heating values than the CDF. The heating value affects the torque being produced, and in order to match that torque with $\mathrm{CDF}$, pure biodiesel and its blends with CDF will have to put more energy in the engine, resulting in higher fuel consumption.

Table 2: Disparity Between Fatty Acid Methyl Ester From Yellow Oleander And Conventional Diesel Fuel

\begin{tabular}{|c|c|c|c|c|c|c|c|c|}
\hline & & \multicolumn{7}{|c|}{ Fuel Blend } \\
\hline S/N & Parameters & B10 & B20 & B30 & B40 & B50 & B100 & Diesel \\
\hline 1. & Specific Gravity & 0.9074 & 0.9028 & 0.8982 & 0.8938 & 0.8890 & 0.8660 & 0.9120 \\
\hline 2. & Calorific value $(\mathrm{Kj} / \mathrm{Kg})$ & 42926 & 42652 & 42378 & 42104 & 41831 & 40462 & 43200 \\
\hline
\end{tabular}




\section{International Journal of Science and Research (IJSR)}

ISSN (Online): 2319-7064

Index Copernicus Value (2013): 6.14 | Impact Factor (2014): 5.611

Table 3: Properties of Diesel, Thevetia Peruviana Biodiesel Blends

\begin{tabular}{|c|l|c|c|}
\hline S/No & Properties & Value for FAME & Value for CDF \\
\hline 1 & Density $\left(\mathrm{g} / \mathrm{m}^{3}\right)$ & 0.866 & $\mathbf{0 . 9 1 2}$ \\
\hline 2 & Kinematic Viscosity at $40^{\circ} \mathrm{C}\left(\mathrm{mm}^{2} / \mathrm{s}\right)$ & 5.10 & $\mathbf{5 . 2 9}$ \\
\hline 4 & Calorific value $(\mathrm{kJ} / \mathrm{kg})$ & 40462 & $\mathbf{4 3 2 0 0}$ \\
\hline 6 & Cetane index & 58.97 & $\mathbf{6 8}$ \\
\hline 7 & Flash point $\left({ }^{0} \mathrm{C}\right)$ & 175 & $\mathbf{1 7 0}$ \\
\hline 8 & Cloud point $\left({ }^{0} \mathrm{C}\right)$ & 3 & $\mathbf{6}$ \\
\hline 9 & Pour point $\left({ }^{0} \mathrm{C}\right)$ & -2 & $\mathbf{5}$ \\
\hline 10 & Percentage yield $(\%)$ & 90 & \\
\hline
\end{tabular}

\section{References}

[1] A. Ramadhas, S. Jayaraj, and C. Muraleedharan, "Use of vegetable oils as IC engine fuels - a review," Renewable energy, vol. 29, pp. 727-742, 2004.

[2] L. Meher, D. V. Sagar, and S. Naik, "Technical aspects of biodiesel production by transesterification-a review," Renewable and sustainable energy reviews, vol. 10, pp. 248-268, 2006.

[3] U. K, "Potential problems and prospects of Biodiesel production in Nigeria," Proceedings of the Nigerian institution of Agricultural Engineers, vol. 27, pp. 73-79, 2005.

[4] K. Umar, "Potential problems and prospects of Biodiesel production in Nigeria," Proceedings of the Nigerian institution of Agricultural Engineers, vol. 27 pp. 73-79, 2005

[5] M. M. Azam, A. Waris, and N. Nahar, "Prospects and potential of fatty acid methyl esters of some nontraditional seed oils for use as biodiesel in India," Biomass and bioenergy, vol. 29, pp. 293-302, 2005.

[6] S. Ibiyemi, V. Fadipe, O. Akinremi, and S. Bako, "Variation in oil composition of Thevetia peruviana Juss' yellow oleander'fruit seeds," Journal of Applied Sciences and Environmental Management, vol. 6, pp. 61-65, 2004.

[7] P. J. Wan and P. J. Wakelyn, Technology and solvents for extracting oilseeds and nonpetroleum oils: The American Oil Chemists Society, 1997.

[8] J. Van Gerpen, "Biodiesel processing and production," Fuel processing technology, vol. 86, pp. 1097-1107, 2005.

[9] F. A. Adamu, "Physico-chemical Properties of Yellow Oleander (Thevetia Peruviana) to ascertain its Suitability for Alternative Biodiesel Production in Nigeria," International Conference on Sub-Sahara Indigenous Knowledge and New Discoveries in the Millenium on $6 /$ 8/ 2015 at Uthman Danfodio University Sokoto PPF I Hall Sokoto Nigeria pp. 67-75, 2015.

[10] T. Balusamy and R. Marappan, "Performance evaluation of direct injection diesel engine with blends of Thevetia peruviana seed oil and diesel," Journal of Scientific and Industrial Research, vol. 66, p. 1035, 2007.

[11]T. D. Durbin and J. M. Norbeck, "Effects of biodiesel blends and Arco EC-diesel on emissions from light heavy-duty diesel vehicles," Environmental science \& technology, vol. 36, pp. 1686-1691, 2002.

[12] W.-G. Wang, D. W. Lyons, N. N. Clark, M. Gautam, and $\mathrm{P}$. Norton, "Emissions from nine heavy trucks fueled by diesel and biodiesel blend without engine modification," Environmental Science \& Technology, vol. 34, pp. 933-939, 2000.

[13] A. EPA, "Comprehensive analysis of biodiesel impacts on exhaust emissions," Draft Technical Report, EPA420-02-0012002.

[14]M. Graboski, R. McCormick, T. Alleman, and A. Herring, "The effect of biodiesel composition on engine emissions from a DDC series 60 diesel engine," National Renewable Energy Laboratory (Report No: NREL/SR510-31461), 2003.

[15] R. L. McCormick, M. S. Graboski, T. L. Alleman, A. M. Herring, and K. S. Tyson, "Impact of biodiesel source material and chemical structure on emissions of criteria pollutants from a heavy-duty engine," Environmental science \& technology, vol. 35, pp. 1742-1747, 2001.

\section{Author Profile}

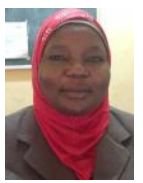

Fati Astapawa Adamu received B.Eng (1996); M.Eng.(2002); PhD (2010) from University of Maiduguri, Federal University of Technology, Yola now MAUTECH, Yola and Abubakar Tafawa Balewa University, Bauchi and Cranfield University UK on split side basis respectively. Presently an Associate Professor in the Department of Agricultural and Environmental Engineering, MAUTECH, Yola from 1998 to date

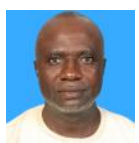

Bala Gambo Jahun received B.Eng. and M.Eng. degrees in Agricultural Engineering from Abubakar Tafawa Balewa University Bauchi, Nigeria and Modibbo Adama University of Technology, Yola Nigeria in 2004 and 2012, respectively. An academic staff at Abubakar Tafawa Balewa University Bauchi Nigeria and a $\mathrm{PhD}$ student at Universiti Putra Malaysia from 2013 to date. His research area is on Soil and Machine dynamics. 